\title{
The Politics of Labour Market Activation: Employability, Exclusion and Active Citizenship
}

\author{
Magnus DAHLSTEDT \\ Institute for Research on Migration, Ethnicity and Society (REMESO), \\ Department of Social and Welfare Studies (ISV), Linköping University, Sweden \\ magnus.dahlstedt@liu.se
}

\begin{abstract}
The article focuses on the formation of the ideal "active citizen" in labour market policy and analyses central ideas and arguments in labour market policy from the 1990s onwards, particularly concerning dominant conceptualisations of work and the ideal working citizen. In Sweden, as well as in many other countries, labour market policies have changed rapidly during the last two decades. Ever since the late 1980s and early 1990s, Swedish labour market policy has primarily been aiming at "activating" citizens, getting them out of passive "welfare dependency" into active "self-employment". With the "activating" labour market policies of the 1990s, work has gradually become a duty, rather than a fundamental social right.
\end{abstract}

Key words: workfare, activation, labour market policy, employability, exclusion

\section{Introduction}

In the new Millennium, there has been a change in welfare policy throughout Europe - and also in other parts of the world. In the European political landscape of the new Millennium, there is a formation of a particular kind of citizenship, a particular conception of what rights and responsibilities the citizen should have and of how the citizen should think and act. The new discourses of "employability" within the European Union describe the citizen as active, as taking responsibility for developing his or her own life. The ideal of a citizenship based upon availability and willingness to enter the labour market (increasingly under imposed inferior terms and conditions of employment) described in European policy documents is encapsulated by that of "active citizenship" (Fejes, 2009). "Active citizenship focuses on whether and how people participate in all spheres of social and 
economic life, the chances and risks they face in trying to do so, and the extent to which they therefore feel that they belong to and have a fair say in the society in which they live" (Commission of the European Communities, 2000: 5). One of the main challenges for policy-makers with respect to participation in "social and economic life" is how to stimulate citizens to become more active, i.e. to develop individualised strategies of (self) activation: "It is the human capacity to create and use knowledge effectively and intelligently, on a continually changing basis, that counts most. To develop this capacity to the full, people need to want and to be able to take their lives into their own hands - to become, in short, active citizens" (Commission of the European Communities, 2000: 7 /emphasis added/). The active citizen is foregrounded, and in this manner "responsibilised" in terms of her/his economic fate, while the structural determination of disadvantage and the hidden and not-so-hidden barriers of discrimination in the labour market are at best acknowledged as surmountable challenges to be overcome through active and persistent job search.

Thus in the new Millennium, the notion of active citizenship has become more and more a mainstream policy narrative in a number of different arenas - not least in the arena of labour market policy, where there is a strong focus on activating citizens and making citizens take responsibility for both finding and keeping a job. The aim of this article is to analyse the notion of "activation" and the formation of ideal "active citizens" in Swedish labour market policy since the 1990s. Taking as a theoretical starting point the work of Michel Foucault and his concept of governmentality, the article analyses central ideas and arguments in labour market policy documents from the 1990s onwards, particularly concerning dominant conceptualisations of work and the ideal working citizen. These conceptualisations are further analysed in relation to issues of ethnicity and the real-life challenges posed in the achievement of the ideal of active citizenship in the context of multi-ethnic Sweden. Although the focus of this article is on changes in Swedish labour market policy, these changes illustrate a wider policy shift occurring in other European countries, but found also in countries outside of Europe, where the notions of activation and active citizenship have become part of the mainstream vocabulary in labour market policy. Studying policy changes in Sweden is particularly interesting, considering the strong social democratic legacy of the Swedish welfare model, which formerly enabled scholars to typify Sweden as an exemplary egalitarian 
and inclusive welfare state. Yet, what was previously a politically embedded "right to work" that was societally guaranteed - and underpinned by generous welfare provisions in circumstances when that right was societally withheld or not delivered upon - has become a duty over the last decades in which the burden of obligation has been progressively shifted from the wider society to the individual, as the Swedish welfare model has been redefined towards a more liberal model emphasising individual autonomy, initiative and freedom of choice (Jacobsson, 2004; Hörnqvist, 2007; Köhler, Thorén and Ulmestig, 2008; Bonoli and Natali, 2011).

The main argument of the article is that, from the 1990s onwards, there has been a significant reorientation in Swedish labour market policy, driven by a rejection of what was seen as a policy encouraging passive "benefit dependency" towards an "activating" policy focused on getting people to support themselves by "standing on their own feet". There has been a transformation from an understanding of work as a social right to an understanding of work as an obligation shared by all citizens, regardless of circumstance In essence, this represents a change of governing rationality in Swedish labour market policy, from a state-oriented form of governing to a form of governing that places the individual at the centre of a nexus of state-mandated (em)powering actions through which the individual can take control of his/her own destiny. An important conclusion of the article is that there is a normalisation in labour market policy of a certain kind of citizen-subject - the active and employable citizen. And, at the same time, there is a construction of certain citizen-subjects as being problematic in one way or another - as passive, unemployable and not sufficiently responsible. In a way, the norm of the active, employable and responsible citizen appears in contrast to these problematic Others. As suggested in this article, the process of normalisation is not least intimately related to issues of ethnicity and the challenges posed by labour market integration in a multi-ethnic Sweden, particularly in discussing the growing problems of exclusion in multi-ethnic suburbs now increasingly prominent throughout Sweden. The analysis indicates that these areas, together with their inhabitants, have increasingly become identified as a serious political problem that needs to be "dealt with". Several of the "activation policies" implemented since the 1990s have also been developed specifically in relation to the sub-urban context. In a way, the multi-ethnic suburb represents the physical embodiment of the Other, the very opposite 
against which the ideal "active citizenship" is given meaning in the new discourses of citizen empowerment.

\section{Theoretical framework}

In line with the ideas of T. H. Marshall (1950), a great deal of literature on citizenship in social and political science has approached citizenship as an institutional order guaranteeing members of society a certain set of rights and obligations. Here, citizenship is understood as a relationship between the state and the individual, in the form of a social contract.

The theoretical point of departure in this article is an understanding of citizenship proceeding from Michel Foucault and his notion of governmentality. According to Foucault (1991), the "objects" of governing are not "passive". They are rather actively governing themselves in certain ways. The concept of governmentality focuses on "different mentalities of government" (Dean, 1999: 16), drawing attention to the complex ways in which thought is linked to a wide range of procedures and techniques. From this point of view, citizenship is seen not as something "given", but rather as something constantly produced and imagined in certain ways (Hindess, 2002). "The citizen is an effect and an instrument of power rather than simply a participant in politics" (Cruikshank, 1999: 5). Thus, it is important to study critically current regimes of the "accepted truth" defining how citizens should appear, behave and think as "good citizens". Citizenship could be seen as an on-going process of forming citizens as certain kind of subjects, where the construction of the norm (the ideal citizen) as well as the others (those lacking the virtues and competences of the ideal citizen) are intimately intertwined.

The classic formula for the governing of citizens in the welfare state is, according to Nikolas Rose, state-centric. It consisted of making the State the primary agent that forms, guides and controls events and people, based on uniform policies. Accordingly, "persons and activities were to be governed through society, that is to say, through acting upon them in relation to a social norm, and constituting their experiences and evaluations in a social form" (Rose, 1996: 40). However, the character of this historically specific formula has gradually changed in the latter part of the 20th Century. In recent decades, there has emerged another formula of governing citizens, characterised by increasingly dispersed and individualised, neo-liberal technologies of government. 
According to Rose we are living today in an "advanced liberal society", which "does not seek to govern through 'society', but through the regulated choices of individual citizens, now constructed as subjects of choices and aspirations to self-actualization and self-fulfilment" (Rose, 1996: 41). The exercise of power involves constant responsibilisation, i.e., the creation of active and responsible citizens who take charge of the entire course of their own lives - from education and work, politics and housing, to family and leisure activities, etc. - on the basis of their own ideals, circumstances, ambitions and, of course, efforts. Thus the object of these interventions is "implanting in citizens the aspiration to pursue their own civility, wellbeing and advancement" (Rose, 1996: 40), i.e., the creation of individuals who are, by their own preferences, motivated, willing and able to be active and take initiative. The creation of such citizens consists of a broad repertoire of technologies, operating in a number of different fields. What they have in common is that they mold subjectivities in ways that spur individuals, on their own, to want to take initiatives, "to shape up", and not be "a burden to society".

\section{The politics of welfare change}

The Swedish welfare model, developed in the post-war period, had an international reputation of being a successful "middle course" between capitalism and socialism. This welfare model was based on the pillars of centralism and universalism, social intervention, and consensus (Rothstein, 1998). According to Rune Premfors (2000: 163), the model was characterised not least by "a readiness to give democracy considerable scope in substantive terms", by the fact that "democratic organising was regarded as natural and desirable in virtually every facet of society", and "an emphasis on lively democratic participation also 'between elections', especially in popular movements and political parties". Starting in the late 1980s, several of the cardinal principles underpinning the "Swedish model" came to be challenged more and more. The model was criticised, among other things, for its alleged inefficiency and highly centralised micro-management, which was said to stand in the way of individual initiative, hampering people's will to participate and have their say (Boréus, 1994). What gradually emerged, according to Premfors (2000: 175), were the contours of "a new Swedish model", with a growing emphasis on power and participation "from below", "a model that combines continued and further elabo- 
rated welfare policies with a highly noticeable decentralisation of politics and administration".

Over the recent decades, the Swedish model has undergone a radical transformation. These welfare reforms were started already in the 1970s and 1980 s, but they accelerated subsequent to the deep economic crisis of the early 1990s (Lindvall, 2004). This transformation reflects an on-going shift in the political landscape, taking place not only in Sweden but also in a number of other countries, where the breadth of the ideological spectrum has contracted as a growing number of political parties have gathered in the centre or towards the right of the political field. It is also reflected in the way in which welfare reforms have been implemented by both social democratic (-1991, 1994-2006) and centre-right governments (1991-94, 2006-). As in many other countries in both Europe and other parts of the world, the Swedish welfare model has witnessed a gradual shift towards a model emphasising individual autonomy, initiative and freedom of choice vis-à-vis governmental control, endeavours to achieve equality and the redistribution of societal resources (Ryner, 2002), i.e., a shift towards an idea of active citizenship.

The Swedish model, widely recognised as a paradigm for a nationally based welfare regime in the social democratic tradition (Esping-Andersen, 1990), has thus step by step undergone a shift towards becoming a postnationally oriented workfare-regime (Jessop, 2002). Flexibility, innovation and international competitiveness constitute the overriding goals that guide the post-nationally oriented welfare regime in all essential respects. In order to make the labour market more flexible and competitive, economic policy is given precedence over social policy. Social welfare expenditure thus becomes viewed more in terms of a cost of production than as a means of redistributing resources. Both social and labour market policy are primarily focused on the supply side of the labour market, i.e., on labour, in an endeavour to create a more competitive "knowledge economy". The transference system is made more cost-effective in order to promote a "climate of enterprise". State intervention by means of social policy measures is viewed less and less as a means of protecting citizens against the destructive forces of an unregulated market economy.

Although it is not a question of a total regime shift in the sense of the traditional "Swedish model" being replaced by a completely new model, it is nonetheless possible to discern a development whereby Sweden in 
a number of respects seems to be moving towards a new welfare regime (Schierup, 2006). These developments have not least taken place in labour market policy over the past two decades (Ryner, 2002).

The right to work is usually counted among the most fundamental rights of social citizenship (Marshall, 1950). Work was also one of the central foundations of the traditional Swedish model. The general Swedish welfare state that took shape during the post-war period was based on a labour market policy doctrine, known as the work line, with the following characteristics: on the one hand full employment, in the sense that everyone who was able to should as far as possible be in work, on the other a solidarity-based wage policy, whose objective was to level out wage differentials. This solidarity-based wage policy was in turn founded on a strong centralised collective bargaining system involving the parties on the labour market, employers and unions (Esping-Andersen, 1990). However, beginning in the 1980s, but accelerating in the 1990s, the labour market policy of the traditional Swedish model underwent quite dramatic changes.

\section{The 1990s: from full employment to full employability}

When we look more closely at the Swedish labour market policy of the 1990 s, a number of central and intimately interwoven themes emerge. In the labour market policy discourse of the 1990s, the main challenge is described as developing measures that could lift the unemployed from a "passive" dependency on benefits to an "active" occupation. In order to succeed with this "activation", a broad repertoire of measures was required aimed at improving the "employability" of the unemployed - but also of those already in employment. At the same time, an increasingly marked polarisation within society, particularly in the metropolitan areas, also created a strong concern about growing levels of "exclusion", with the excluded ones being at risk of developing a distinct mentality separating them from the rest of society (see Schierup, 2000; Junestav, 2004; Hörnqvist, 2007). We will return to the issue of exclusion and metropolitan policy later on in the article.

The idea that the main task of labour market policy should be to stimulate activity - employment or measures to promote employment - rather than relying on and supporting a passive dependency on benefits dominated Swedish labour market policy during the whole post-war period, but it really came to the fore in the climate created by the deep economic crisis 
witnessed during the early 1990s - which was characterised by growing inequality, record levels of inflation and mass unemployment at a level not witnessed since the depression of the 1930s. The crisis of the 1990s seriously challenged the Swedish model and had a major effect on Swedish politics - not least in the area of labour market policy.

How then were more citizens to be activated through work? In the labour policy discourse of the 1990s, the main answer to this question both in Sweden and the EU was employability. According to an idea that grew stronger and stronger during the 1990s, an individual's employment is dependent on his or her power of initiative (Garsten and Jacobsson, 2004; Hörnqvist, 2007). Expressed simply, individuals are themselves responsible for their own successes and failures in the labour market. In order to get a job, the individual must have the "right" qualities. Those seeking work have to be(come) employable. In order to increase the level of employment, a broad repertoire of measures is therefore required to improve the employability not only of the unemployed but also of those in work.

As the focus was increasingly directed at formulating measures to produce employability, the character of labour market policy gradually shifted. The problem was redefined. Having previously been primarily a question of a lack of job opportunities, employment policy increasingly came to be defined in terms of a shortfall in employability. The direction of the policy was shifted from initiatives focused on producing full employment to an endeavour to create full employability. In Sweden, however, this shift had already been initiated prior to the crisis of the 1990s as a result of the social democratic government's prioritisation of the battle against inflation over the goal of full employment, something which has subsequently continued as part of Sweden's intensified collaboration with the EU (Jacobsson, 2004).

With the shift from full employment to full employability, state responsibility for labour market policy is clearly circumscribed. More space is left open to private interests. The focus becomes directed at the supply side of the labour market, "to 'flexibilise' and 'motivate' the unemployed" (Peck and Theodore, 2000: 729). Activating measures are developed in order to cultivate the unemployed, getting them to want to become more employable. This process is described in terms of lifelong learning, whereby those who want to find work and those who want to keep their jobs are continuously to work on themselves, improve their competitiveness, update their 
qualifications, undergo additional education, develop the "right" attitude (in terms of initiative, enterprise and flexibility) (Fogde, 2007; Tesfahuney and Dahlstedt, 2008).

\section{Adult education and active citizenship}

As mentioned above, it is not only within the context of the Swedish labour market policy debate that the ideal active and employable worker emerged during the 1990s. Corresponding ideas were simultaneously to be found among the social and labour market policy guidelines of the European Union (Garsten and Jacobsson, 2004; Schierup, Hansen and Castles, 2006). In the Swedish context, the idea of employability became particularly conspicuous during the mid-1990s, with the social democratic government's launch of a policy labelled the Adult Education Initiative (Kunskapslyftet), a largescale labour market and education policy initiative intended to improve citizens' "participation in social progress, employability and opportunities for further education" (Government Bill 1995/96:222). The government's labour market policy goal during the mid-1990s was to halve the level of "open unemployment". Education was viewed as an indispensable means of achieving this goal and of "creating better conditions for growth over the longer term" (Government Bill 1995/96:222: 6.12). Among a number of measures introduced over the course of a five-year period, adult education was expanded substantially, with the ambition being to create space for at least 100,000 new students each year.

When motivating the Adult Education Initiative, it was repeatedly argued that education and competence constitute important factors in the context of rising global competition. "Sweden will compete with competence, not with low wages", the government proclaimed. "In order to create a longterm, stable increase in wealth with a fair, rational distribution of incomes, Sweden must make a consistent commitment to the swift development of the knowledge-based society" (Government Bill 1995/96:222: 6.2f). The government's statements about developing Sweden as a knowledge-based society referred to two central lines of thought that characterised EU policy at the time, namely lifelong learning and social exclusion (Schierup, 2000; Garsten and Jacobsson, 2004). The government concluded that a commitment of this kind "requires the strengthening of youth education and higher education, a lifelong learning and an adult education initiative for those poorly educated groups of adults who otherwise risk finding themselves 
outside the job market and becoming marginalised in relation to society" (Government Bill 1995/96:222: 6.3).

The Adult Education Initiative outlined the responsibilities of the state and the individual respectively. The Labour Market Administration Agency was assigned the responsibility of both "requiring people to actively seek work" and "helping jobseekers to take the steps required in order to be able to compete for the vacant jobs that are available" (Government Bill 1995/96:222: 7.17). An "individual action plan" that may be viewed as an "explicit contract between the individual and society" was formulated for every jobseeker (Government Bill 1995/96:222: 7.20). The contract can be seen as a responsibilising technique, placing a strong emphasis on the responsibilities of the individual jobseeker him/herself. The jobseekers were "to have a clearly defined responsibility to themselves get to grips with and sort out their situation as far as is possible and reasonable" (Government Bill 1995/96:222: 7.27). In other words, the task of the state was not to govern the jobseekers. They were to do the work themselves. The task of the state was rather to help jobseekers to help themselves. Once again, these measures were intended to address passivity and dependence - the solution was quite simply the opposite, activity and autonomy, active citizenship.

\section{The new Millennium: restoring the work line}

The focus on activation is also a dominant theme in the labour market policy of the new Millennium. Activation was largely one of the main topics on the political agenda in the election of 2006. Prior to the election, the centre-right parliamentary political parties (the Moderates, the Liberals, the Centre Party and the Christian Democrats) declared their intention to challenge the Social Democrat government in office by, for the first time in the history of Swedish politics, forming an alternative government of the centre-right, the Alliance for Sweden (hereafter abbreviated to the Alliance). The centre-right parliamentary parties had never previously joined together in this way prior to an upcoming election in order to offer the possibility of a united alternative government.

During the election campaign, the Alliance succeeded in taking command of the political debate by defining the political dilemma as a choice between two alternatives: work or exclusion, enterprise or benefits, bottom up or top down. According to the Alliance, which would go on to win the 
election, the critical line of conflict in today's society is no longer that between labour and capital, i.e. the interpretation that constituted the foundation for the building of the "Swedish model", but rather that between work and exclusion. The Alliance's central definition of the problem is concisely formulated in the 2006 declaration of government: "The progress of society is dependent on people's will to work, their capacity to assume responsibility, their inventiveness, enterprise and courage to invest in the future. Over a million people stand outside the labour market. Despite strong economic growth, there is mass unemployment" (The Government, 2006: 2). The declaration of government states that the most important political challenge consists in ensuring the inclusion into the community of those who find themselves in "the Sweden of the excluded" - those who make no contribution to the social economy through work, the unemployed, those who are dependent on benefits - by having them provide for themselves. "Sweden needs a vigorous programme for more jobs throughout Sweden, which makes it more rewarding to work and easier to provide employment. The thresholds to entry onto the labour market must be lowered and working more or taking on more responsibility must be rewarded. [...] High taxes, complicated regulations and far-reaching commitments mean that employers are afraid to employ people" (The Government, 2006: 2). Prior to the election, by successfully exerting pressure on public opinion, the Alliance succeeded in dividing Swedish politics into two opposing camps: those advocating work and activity (and who thereby supported the Alliance) and those advocating exclusion and passivity (and who thereby supported the government in office at the time). It appeared quite impossible to even imagine that there might be any additional alternatives other than these two. The language used often had powerful moral undertones, with work - the work line, the obligation to work and to "pay one's way" - being assigned a superior moral status. "The work line and the value of work shall be restored." Work is viewed as a fundamental precondition for human existence: "Having a meaningful occupation is important for individual self-determination, quality of life and participation. Feeling needed weaves networks of security between individuals and produces a situation where people dare to assume responsibility and to grow in line with the tasks that face them" (The Government, 2006: 13f). For the Alliance, work, i.e., contributing to the economy rather than receiving benefits, constitutes the single most important element in a responsible, active citizenship. 


\section{Old and new Moderates}

The moral-political narrative of the Alliance combines "new" elements with "old" in a very palpable way. At the same time as the Alliance is careful to distance itself from social democracy and its "passivising" benefits policy, its emphasis on the "work line" contain clear continuities with the ideals of the earlier labour movement - discipline, conscientiousness and a sense of duty. During the election campaign, the Moderates (the largest of the centre-right parliamentary parties) also proclaimed themselves to be the new Moderates, "the new workers' party", the party that was taking on the task of restoring "the value of work", which had been lost through the large-scale system building of the social democratic movement.

For the Alliance however, employment is not only a fundamental precondition of human existence. The declaration of government states powerfully that increased employment is necessary not least in order for Sweden to be able to maintain her position in the context of a seemingly harsher climate of global competition. The theme of work as a means of improving Swedish competitiveness is repeatedly emphasised by the Alliance. "Tougher global competition means an increased risk for jobs moving abroad" (The Government, 2006: 2). "Entrepreneurship and the spirit of enterprise are critical to increasing employment, to laying the foundations for continued progress across the whole of Sweden and for strengthening Sweden's position in the world" (The Government, 2006: 1). In order to assert Sweden's position in relation to the global competition, the Alliance stresses that the Swedish labour market needs to be made more flexible, and adapted to the demands of an increasingly globalised economy: "Sweden needs a well-functioning and flexible labour market [...]" (Skr. 2006/07:23: 6).

Several reforms of the traditional Swedish model are regarded as necessary in order to increase the level of employment. One of the most controversial proposals that was both introduced and implemented at the beginning of the new government's period in office involved the introduction of a significantly more restrictive unemployment insurance system. The Alliance views generous unemployment insurance as an important part of a functioning labour market, since it can lead to greater flexibility. "People who are able to receive financial compensation during periods of temporary unemployment feel secure and have the courage to test new occupations." If unemployment insurance is too generous, however, it diminishes the incentive to work among the unemployed. "An overly generous system of 
unemployment insurance on the other hand risks obstructing people's desire to find a new job during periods of unemployment" (Skr. 2006/07:23: 59). For this reason, unemployment insurance is transformed into a "readjustment insurance" that is intended to lead to increased employment. "It must always pay more to work than to be unemployed" (Skr. 2006/07:23: 47). For the Alliance it is not however sufficient to "tighten benefit levels and the right to benefit". In order to increase the incentive among the unemployed to seek work, unemployment insurance itself needs to be "made more insurance-like" in the sense of "reducing the level of state intervention and having the insured party bear a larger proportion of the costs" Skr. 2006/07:23: 60).

\section{The multi-ethnic suburb and the threat of exclusion}

The concept of exclusion has an important role in the political vocabulary of the Alliance. For the Alliance, exclusion is referred to as the problematic opposite to the idealised active citizenship, legitimating the various activating measures proposed. But the concept of exclusion has been used in Swedish labour market policy ever since the 1990s, particularly in relation to issues of ethnicity and the challenges of multi-ethnic suburbs throughout the country. These areas, as well as their inhabitants, have been seen as one of the most urgent challenges for Swedish labour market policy - and welfare policy more widely (Urban, 2005).

\section{Unemployment, polarisation and "disadvantaged neighbourhoods"}

In the 1998 government bill Progress and justice - a policy for the metropolitan areas in the first decade of the 21st century (Government Bill 1997/98:165) the social democratic government introduced an integrated policy for the metropolitan areas for the first time (Tedros, 2008). The bill presents an alarming description of the situation in the country's metropolitan areas. During the 1990s, the cost of income support payments in the three metropolitan counties had almost tripled. Towards the end of the 1990s, the level of employment in what the government referred to as the "most disadvantaged city districts" stood at between 30 and 40 percent. Against this background, the government concluded that: "One of the most important goals for metropolitan policy is to improve the level of employment in disadvantaged neighbourhoods" (Government Bill 1997/98:165: 82). The criti- 
cal challenge for metropolitan policy was that of how to turn passivity and exclusion into activity and participation. When it came to the development of a policy intended to activate, the importance of access to a job of one's own naturally assumed a central position. "Since participation in the life of the community and the possibilities for a good financial, social and cultural life are strongly associated with having a job and being able to provide for oneself, this is critical to continued social progress" (Government Bill 1997/98:165: 82f). Once again, emphasis was placed on the fundamental importance of work to both the individual citizen and to society at large. It was first and foremost through work, through working, that the citizen would become part of the community in a meaningful way. The opposite, being out of work or "dependent on benefits", placed citizens at risk of being drawn into a vicious spiral that could in time lead to permanent exclusion. "Unemployment is most serious for those persons who are excluded from the job market for long periods. They experience greater risks to their health than many other groups, their long-term income increases more slowly, they lose competence and therefore run the risk of becoming permanently cut off from the job market. [...] In practice they become trapped in unemployment and dependency on benefits" Government Bill 1997/98:165: 83). As they had previously, the government stressed the necessity of reacting to the threat of becoming trapped, of exclusion and dependency on benefits, by means of active rather than passive measures. According to the government "extended periods of nothing but benefits can lead to people becoming passive and losing confidence in themselves". In order to avoid this kind of passivity, the emphasis was placed on the necessity for measures to produce employability which "both maintain and improve the competence of those seeking work" (Government Bill 1997/98:165: 83).

The government pointed out that its policy was based on an "explicit reciprocity, in which the individual has both rights and obligations". On the one hand, the obligations of society were focused on the unemployed individual. Society had a duty to offer various measures and programmes to improve the unemployed individual's employability. "On the one hand, society is prepared to support those who have a hard time finding work, both financially and by means of active measures." At the same time, the unemployed individual had an obligation to participate actively in these measures and programmes. "On the other hand, society expects unemployed individuals to actively utilise their own resources and opportunities, 
and to be prepared take any suitable job" (Government Bill 1997/98:165: 83f). However, a particularly strong emphasis was placed on the individual's obligations vis-à-vis society. "The right to receive payments from the various benefit systems is linked to some form of condition or requirement for the individual to do something in return." The government bill notes that what was required of benefit recipients in return could take different forms: on the one hand the unemployed individual might be required to "seek and accept a new job even outside of the occupation or profession in which he or she has previously worked" and on the other "to accept a different wage, to move or to commute to work, to retrain or to participate in job training measures" (Government Bill 1997/98:165: 88f).

At the same time, the centre-right opposition parties directed strong criticism at several aspects at what they regarded to be a too traditionally state-oriented, top-down policy. "It is not enough to make people employable", the Liberals noted in an opposition bill in the area of integration policy (Mot. 1997/98:Sf8). A policy to produce real employability "needs fresh ideas", the party stated, requiring amongst other things "that labour market policy is not viewed as a storage system and that people are viewed as being capable". The party emphasised that the system of state benefits needed to be overhauled in order to promote employment and free enterprise: "The benefits systems have to become opportunities for life, not prisons". The party argued that in areas characterised by high levels of unemployment, and where a large proportion of the residents were forced to live outside of the regular labour market for long periods of time, a distinctive attitude tended to develop over time - particularly among the younger generation: "The children and youths who grow up in an environment where there is no relationship between work and income do not of course themselves learn this relationship. Instead they grow up in an environment that is no doubt poisoned by discontent and frustration over this situation. It is not strange that this becomes transformed into aggression and even hatred". With time, emotional currents of this kind could produce major challenges in relation to the provision of welfare and security. Similar ideas were also expressed by other opposition parties.

\section{The emergence of cultures of exclusion}

In 1999, the Moderates appointed a special Working Group against Social Segregation and Exclusion. One of the central figures in this working 
group was Mauricio Rojas, an economic historian, debater and at the time vice executive director of a business-oriented think-tank called Timbro. In a report entitled Renewal and citizen power, the Working Group states that Swedish integration policy has been a large-scale failure, a result of "counterproductive social engineering". The Swedish welfare system as a whole is described as "a social project based on social planning ideals, centralisation, doing everything on a large scale, and uniformity" (Moderata samlingspartiet, 1999: 3, 4).

Around the country, the project is said to have led over time to the establishment of a "benefit-financed exclusion and a devastating benefit culture", not least in increasingly marginalised suburban environments where people's life situation "does not revolve around work and enterprise but around the art of maximising benefits and living on the margins of society" (Moderata samlingspartiet, 1999: 20). The ideas are largely the same as those of the Liberals, even if the presentation is rather more direct: Exclusion is defined in terms of both unemployment and morals. To combat passivising from above the Working Group proposes citizen power from below. According to the Working Group, the only reasonable alternative is to "create more competition, openness and flexibility in our societal economy" and to "give the citizens the simple but very important power to behave as customers and not as clients" (Moderata samlingspartiet, 1999: 22, 26).

Shortly after the Working Group had completed its work, Rojas left the Moderates to join the Liberals, not without fuss, and became the latter party's new spokesman on integration policy. Rojas soon had a major impact on the party's work in relation to "suburban Sweden". Largely thanks to the strategic development of a strong profile on the "integration question", the Liberals had a very good 2002 election, in which they almost tripled their level of electoral support in comparison with the preceding election, from 4.6 to 13.3 percent of the popular vote (see Dahlstedt, 2010).

In December 2004, the party leader Lars Leijonborg, together with Rojas, who was now a newly elected Member of Parliament, presented a new report from the party entitled The map of exclusion (Folkpartiet liberalerna, 2004). The report charts the "development of exclusion" in multi-ethnic suburban environments across Sweden. The picture of suburban life presented in the report is a dismal one. Leijonborg and Rojas (2004) conclude that "A new social landscape has emerged in Sweden, a landscape characterised by exclusion from the labour market, by residential segregation, 
dependency on benefits, powerlessness and vulnerability. It is about tens of thousands of people among whom the vital processes of social mobility have ceased to function and residential neighbourhoods whose life is almost completely lived under socio-economic conditions that are strikingly different from those of the rest of society".

The report emphasises that "islands of profound exclusion" were now to be found "in almost all large and medium sized Swedish cities" (Folkpartiet liberalerna, 2004: 8). Sweden is said to be "dangerously close to the point when ethnic and social conflicts may degenerate into open riots and other extremely tragic events" (Folkpartiet liberalerna, 2004: 6). In the definition of the problem that permeates not only the report itself but also other statements and documents in which the party focuses on "the suburban problem", the morals of the residents are assigned a central role (e.g. Mot. 2004/05:Sf288). One particularly serious problem relates to the "cultural framework of reference" that is said to be developing in "the neighbourhoods of exclusion", in part as a consequence of immigration and "significant cultural differences" between "immigrant" and "nativeborn groups" and in part as a consequence of the fact that the residents are living in the shadow of, or outside, central social arenas (Folkpartiet liberalerna, 2004: 8).

As the social democratic government had done in the 1998 metropolitan policy bill, the report published by the Liberals emphasises that the central problem lies largely in the high levels of unemployment found in the "neighbourhoods of exclusion". In spite of this, the report argues that once it has taken shape, the specific morality that is generated by these conditions has its own, independent dynamic. "When life for a majority of those living in a given area is entirely pervaded by socio-economic conditions and cultural frames of reference that are radically different from those of the rest of society, individual disadvantage is transformed into collective processes with a dynamic of their own." In this description, the "culture of exclusion" is divorced from the surrounding social context. The report describes a downward spiral "where exclusion generates more exclusion and where the culture of exclusion is passed on to subsequent generations", and where "that which started as an effect - exclusion - becomes transformed into a cause" (Folkpartiet liberalerna, 2004: 9).

Another important idea in the party's view on the "neighbourhoods of exclusion" is recognisable from the Moderates' Working Group, namely the 
idea that the "culture of exclusion" had been promoted by the far-reaching "overprotective and overindulgent policies" of the state. The implementation of such policies throughout the post-war period had in practice stripped people of their creativity and initiative in favour of solutions formulated from above. According to the Liberals, the benefits system in itself created a "dependency" from which it was very difficult to recover. "There is a fast habit-forming effect", the party argues in an opposition bill, "Those who become used to being provided for by others will after a time come to see this as a natural condition" (Mot. 2004/05:Sf288: 33). In line with this idea, Leijonborg and Rojas (2004) argued that it was high time for a "change of perspective that opens the way for an inclusive policy for progress based on individual empowerment instead of indulgence, on work instead of benefits". With this the two were referring back to a successful slogan from the 2002 election: Making demands is caring. "A new ability is needed to dare to insist that all individuals should do as much as they are capable of - to make demands is to care. Because exclusion cannot be broken from the outside. It is only from the inside, when those affected themselves take things into their own hands, that anything positive can happen" (Leijonborg and Rojas, 2004). As the argument was based on a strong normative assumption about independence constituting the ideal, the party proposed a series of activating measures, where the obligation to work was advocated as an alternative to the passivising (right to) welfare. The idea of activation runs as a central theme through the battery of proposed measures presented in order to bring about renewal in the "neighbourhoods of exclusion".

This use of the integration issue by the Liberals as a means of attracting political attention has had a major effect on the integration policy debate over recent years, not least during the 2002 general election campaign, in which the party was able to take command of the political debate by directing the focus at making "increased demands", amongst other things in relation to the Swedish language skills of "immigrants" (Dahlstedt, 2010). Following the change in government following the 2006 election, the party's agenda in the areas of metropolitan and integration policy has also had a major effect at the governmental level. The Liberal politician Nyamko Sabuni was also appointed to the post of Minister for Integration.

This brings us back to the general election of 2006 and the Alliance's endeavours to "restore the work line". The principal direction followed by the Government's metropolitan and integration policy was stated directly 
in 2006 in the declaration of government: "One consistent element in the government's integration policy will be the removal of obstacles and the opening up of opportunities" (The Government, 2006: 7). In line with an overarching endeavour to "restore the work line", the government emphasises that employment and enterprise constitute the path out of the state of exclusion in which many "immigrants" are forced to live. It is therefore essential that "people who have migrated to Sweden are respected as individuals and not regarded as a homogeneous collective" (The Government, 2006: 7). In contrast to previous initiatives, which had been too much comprised of measures specifically focused on "immigrants", a more general "emancipatory" policy is proposed: "Beyond the initial period in Sweden, no separate policy is required for immigrants, but rather a policy that frees people's inherent power and breaks down the exclusion that has become established in Sweden" (The Government, 2006: 7).

\section{Concluding reflections}

The focus of this article has been on the formation of the ideal "active citizen" in Swedish labour market policy from the 1990s onwards, particularly concerning dominant conceptualisations of work and the ideal working citizen. Since the beginning of the 1990s, when Sweden experienced the most severe economic crisis since the 1930s, there has been an ideal of active citizenship. This notion of citizenship safeguards and promotes the autonomy, initiative and freedom of the individual vis-à-vis state efforts to exert control, to redistribute resources and to promote equality. Here, both centre-right and social democratic governments have increasingly emphasised work as a duty, rather than a right, of citizenship. This change is part of a more general change in the way of looking at and organising welfare provision, not only in Sweden, but also in many other countries both within and outside Europe. Even though there are differences between social democratic and centre-right alternative governments with regard to the view of welfare and state intervention, a number of striking similarities can nonetheless be discerned, not least in the way both emphasise the importance of activating measures, the desire to improve the individual's employability and an ever-present threat of growing exclusion.

The policies of labour market activation developed since the 1990s appear as complex neo-liberal forms of governance. On the one hand, they are libertarian, in the sense that they strive to motivate and release the 
creativity of the individual. On the other hand, they are disciplinary, in the sense that they emphasise work as an obligation and require something in return (Hörnqvist, 2007). In the traditional Swedish model, there was also a strong emphasis on work as citizen obligation - all those who were able to were expected to work and "pay their own way". However, the obligation to work was balanced both by the solidarity-based wage policy's efforts to ensure a reasonable wage level and by the public benefits system for those who for various reasons were unable to get a job (Junestav, 2004). The labour market policy that developed as the 1990s progressed, however, individualises the question of the citizen's right to work. Referring to Rose (1996), we could talk about a change of governing rationality, from a state-oriented form of governing to a form of governing more oriented towards the individual. Work is transformed here into a question of the individual's own qualifications and characteristics, ambitions and abilities. "Passivising" benefits are replaced by "employment-activating" interventions, first and foremost intended to "do something about" those individuals who are unemployed, by making them more employable. Increased levels of responsibility and more demands are placed on the individual job-seeker: Activate yourselves! At the same time, the state increasingly disclaims responsibility for the outcomes of labour market policy. If one is unemployed and remains unemployed, then in the final analysis he/she has nobody but himself/herself to blame. In order to get a job one needs to work on one's own employability.

The central welfare policy issue of resource redistribution has been more or less removed from the political agenda and, as a result, society's responsibility for guaranteeing citizens a reasonable level of welfare gradually becomes undermined. The welfare of citizens, which was guaranteed during the golden age of the Swedish model by the transfer and social insurance systems of the welfare state, is increasingly determined once again by the value of their work (Esping-Andersen, 1990; Johansson, 2001). The contours of a new Swedish model are emerging, with this new model emphasising the obligations, duties and moral fibre of citizens over their rights (Junestav, 2004; Schierup, 2006).

This transformation is more than visible in Swedish metropolitan policy. The multi-ethnic suburb represents the Other, in opposition to which the ideal "active citizenship" is given meaning (Tesfahuney and Dahlstedt, 2008). The issue that has repeatedly been raised in the context of the met- 
ropolitan policy debate since the late 1990s is how to get the suburban population to transform its morality of impotence, dependence and passivity into the diligence, confidence, employability and enterprise of the surrounding Swedish society. Everything seems to hang on the desire and ambition of the suburban residents themselves. Exclusion can only be resolved from the inside. Suburban residents may often live under difficult conditions, find themselves in a situation of profound exclusion, suffering as a result of a lack of knowledge of the Swedish language or of Swedish society, but the Solution to the serious problems associated with this exclusion are nonetheless to be found within those who are often categorised as constituting the Problem. Even the excluded, those who find themselves in a state of exclusion, can "take control over their own lives" and find their way into the community - if only they are given the opportunity. On the basis of this type of argument, a large number of activating measures or efforts - intended to motivate, provide opportunities, remove obstacles - are also directed specifically at multi-ethnic suburbs.

The transformation from problem to resource, consuming to nourishing, passive to active, unqualified to employable is bidirectional. The relationship is not only reciprocal - it is also hierarchical. There is always a "we" who are inviting "them" to join us. In exchange for being offered initiatives, advantages and opportunities, the inhabitants of the suburbs are expected to do something in return. Those who are offered the opportunity to participate through employment and inclusion into the wider community are subjected at the same time to a large number of - often unspoken demands, which may assume many different forms. These demands are focused in particular on residents classified as "immigrants" who, in a variety of different situations, are required to "prove" not only their willingness to work but also their commitment and loyalty towards Swedish society.

The requirements for being allowed into the community are flexibility, responsibility, employability, and enterprise. Those who possess these "values" are allowed in, the rest continue to be set aside. "Those who refuse to become responsible [...] have also refused the offer to become members of our moral community. Hence, for them, harsh measures are entirely appropriate. Three strikes and you are out: citizenship becomes conditional upon conduct" (Rose, 2000: 335). More or less any type of disciplinary measure is possible, the only limits being those set by the imagination. These measures may involve significantly lower benefit levels or the introduction 
of language tests as a requirement for "immigrants" to become Swedish citizens. The unemployed may be compelled to move to where there are jobs. They can be compelled to apply for a certain number of jobs, or to look for work for a specified number of hours every day.

As the emphasis on the obligation to work is gradually intensified in relation to Swedish welfare policy, the conditions for forcefully combating social and ethnic hierarchies on the labour market and in other sectors of Swedish society become worse and worse. This kind of policy not only has extremely important consequences for the social rights of the welfare state, such as the right to a reasonable income, security of employment, reasonable housing, educational equality etc. It also involves a risk for the gradual undermining of the fundamental civil and political rights that citizens have come to regard as being guaranteed. As their social rights become increasingly circumscribed, suburban residents with an "immigrant background", together with other subordinate groups, also find it increasingly difficult in practice to take advantage of their civil and political rights - i.e., to express them and struggle to satisfy their needs and interests in various ways. Thus, at least over the longer term, the changes to the welfare state that have taken place in Sweden over recent decades - and that continue to take place - have a number of very important consequences for the ideal of a vital, functioning democracy.

\section{REFERENCES}

Bonoli, Giuliano and Natali, David (2011). The Politics of the New Welfare States in Western Europe. EUI Working Paper RSCAS 2011/17.

Boréus, Kristina (1994). Högervåg. Stockholm: Tiden.

Commission of the European Communities (2000). A Memorandum on Lifelong Learning (Commission staff working paper, SEC 1832). Brussels.

Cruikshank, Barbara (1999). The Will to Empower: Democratic Citizens and Other Subjects. Ithaca: Cornell University Press.

Dahlstedt, Magnus (2010). "Hårda nypor för ett mjukt samhälle? Om medialisering och rasifiering i utspelspolitikens Sverige", Sociologisk Forskning, 47 (3): $35-56$.

Dean, Mitchell (1999). Governmentality: Power and Rule in Modern Society. London and Thousand Oaks: Sage.

Esping-Andersen, Gøsta (1990) The Three Worlds of Welfare Capitalism. Cambridge: Polity Press.

Fejes, Andreas (2009) "Active Democratic Citizenship and Lifelong Learning: A Governmentality Analysis", in: Michal Bron Jr, Paula Guimarães and Rui 
Vieira de Castro (eds). The State, Civil Society and the Citizen: Exploring Relationships in the Field of Adult Education in Europe. Frankfurt am Main: Peter Lang, pp. 79-95.

Fogde, Marinette (2007). "The Making of an Employable Individual", in: Birgitta Höijer (ed.). Ideological Horizons in Media and Citizen Discourses: Theoretical and Methodological Approaches. Gothenburg: Nordicom, pp. 131-146.

Folkpartiet liberalerna (2004). Utanförskapets karta. Stockholm.

Foucault, Michel (1991). "On Governmentality", in: Graham Burchell, Colin Gordon and Peter Miller (eds). The Foucault Effect: Studies in Governmentality. Brighton: Harvester, pp. 87-104.

Garsten, Christina and Jacobsson, Kerstin (eds) (2004). Learning to Be Employable: New Agendas on Work, Responsibility and Learning in a Globalizing World. Basingstoke: Palgrave Macmillan.

Government Bill 1995/96:222. Vissa åtgärder för att halvera arbetslösheten till år 2000, ändrade anslag för budgetåret 1995/96, finansiering m.m.

Government Bill 1997/98:165. Utveckling och rättvisa - en politik för storstaden på 2000-talet.

Hindess, Barry (2002) "Neo-liberal Citizenship", Citizenship Studies, 6 (2): 127143. doi: $10.1080 / 13621020220142932$

Hörnqvist, Magnus (2007). The Organised Nature of Power: On Productive and Repressive Interventions Based on Considerations of Risk (Diss.). Stockholm: Department of Criminology, Stockholm University.

Jacobsson, Kerstin (2004). "A European Politics for Employability: The Political Discourse on Employability of the EU and the OECD”, in: Christina Garsten and Kerstin Jacobsson (eds). Learning to Be Employable: New Agendas on Work, Responsibility and Learning in a Globalizing World. Basingstoke: Palgrave Macmillan, pp. 42-62.

Jessop, Bob (2002). The Future of the Capitalist State. Cambridge: Polity Press. Johansson, Håkan (2001). "Activation Policies in the Nordic Countries: Social Democratic Universalism under Pressure", Journal of European Area Studies, 9 (1): 63-77. doi: 10.1080/14608460120061957

Junestav, Malin (2004). Arbetslinjer i svensk socialpolitisk debatt och lagstiftning 1930-2001 (Diss.). Uppsala: Ekonomisk-historiska institutionen, Uppsala universitet.

Köhler, P[eter] A., Thorén, K[atarina] H. and Ulmestig, R[ickard] (2008). "Activation Policies in Sweden: 'Something Old, Something New, Something Borrowed and Something Blue",, in: Werner Eichhorst, Otto Kaufmann and Regina Konle-Seidl (eds). Bringing the Jobless into Work? Experiences with Activation Schemes in Europe and the US. Berlin: Springer, pp. 257-296. doi: 10.1007/9783-540-77435-8_7

Leijonborg, Lars and Rojas, Mauricio (2004). “"Explosiv ökning av antalet utsatta bostadsområden"', Dagens Nyheter, 5 December.

Lindvall, Johannes (2004). The Politics of Purpose: Macroeconomic Policy in Sweden After the Golden Age (Diss.). Gothenburg: Department of Political Science, University of Gothenburg. 
Marshall, T[homas] H[umphrey] (1950). Citizenship and Social Class, and Other Essays. Cambridge: Cambridge University Press.

Moderata samlingspartiet (1999). Förnyelse och medborgarmakt. Arbetsgruppen mot social segregation och utanförskap (Stämmohandlingar, band 1).

Mot. 1997/98:Sf8. "Med anledning av Prop. 1997/98: 16 Sverige, framtiden och mångfalden - från invandrarpolitik till integrationspolitik" [Folkpartiet liberalerna].

Mot. 2004/05:Sf288. "Egenmakt och arbete - den liberala vägen till integration" [Folkpartiet liberalerna].

Peck, J[amie] and Theodore, N[ik] (2000). "Beyond 'Employability", Cambridge Journal of Economics, 24 (6): 729-749. doi: 10.1093/cje/24.6.729

Premfors, Rune (2000). Den starka demokratin. Stockholm: Atlas.

Rose, Nikolas (1996). "Governing 'advanced' liberal democracies", in: Andrew Barry, Thomas Osborne and Nikolas Rose (eds). Foucault and Political Reason: Liberalism, Neo-liberalism and Rationalities of Government. London: UCL Press, pp. 37-64.

Rose, Nikolas (2000). “Government and Control”, British Journal of Criminology, 40 (2): 321-339. doi: 10.1093/bjc/40.2.321

Rothstein, Bo (1998). Just Institutions Matter: The Moral and Political Logic of the Universal Welfare State. Cambridge: Cambridge University Press.

Ryner, J. Magnus (2002). Capitalist Restructuring, Globalisation and the Third Way: Lessons from the Swedish Model. London: Routledge.

Schierup, Carl-Ulrik (2000). "Multipoverty Europe: Reflections on Migration, Citizenship and Social Exclusion in the European Union and the United States", in: Jagdish Gundara and Sidney Jacobs (eds). Intercultural Europe: Diversity and Social Policy. Aldershot: Ashgate, pp. 129-150.

Schierup, Carl-Ulrik (2006). "Den sociala exkluderingen i Sverige: Migration, arbetsmarknad och välfärdsstat i förändring", in: Paulina de los Reyes (ed.). Arbetslivets (o)synliga murar (SOU 2006:59). Stockholm: Statens offentliga utredningar, pp. 35-99.

Schierup, Carl-Ulrik, Hansen, Peo and Castles, Stephen (2006). Migration, Citizenship, and the European Welfare State: A European Dilemma. Oxford: Oxford University Press.

Skr. 2006/07:23. Sveriges handlingsprogram för tillväxt och sysselsättning 20062008.

Tedros, Adiam (2008). Utanför storstaden: Konkurrerande framställningar av förorten $i$ svensk storstadspolitik (Diss.). Göteborg: Förvaltningshögskolan, Göteborgs universitet.

Tesfahuney, Mekonnen and Dahlstedt, Magnus (2008). “Tärningen är kastad! Entreprenörialism, kasinosamhället och postpolitikens moral”, in: Magnus Dahlstedt and Mekonnen Tesfahuney (eds). Den bästa av världar? Betraktelser över en postpolitisk samtid. Stockholm: Tankekraft, pp. 31-72.

The Government (2006). Regeringsförklaringen 6 oktober 2006. http://www.regeringen.se/sb/d/6316/a/70232.

Urban, Susanne (2005). Att ordna staden. Lund: Arkiv. 


\title{
Politika aktivacije tržišta rada: zapošljivost, isključenost $i$ aktivni građanski status
}

\author{
Magnus DAHLSTEDT \\ Institut za istraživanje migracija, etničnosti i društva (REMESO), Odjel za \\ društvene znanosti i studij socijalnog rada (ISV), Linköpinško sveučilište, \\ Švedska \\ magnus.dahlstedt@liu.se
}

U članku se usredotočuje na oblikovanje idealnoga »aktivnog građanina« u okviru politike tržišta rada te se analiziraju središnje ideje i argumenti u politici tržišta rada od devedesetih godina 20. stoljeća naovamo, osobito s obzirom na dominantne konceptualizacije rada i idealnoga zaposlenog građanina. U Švedskoj su se, kao i u brojnim drugim zemljama, politike tržišta rada brzo mijenjale tijekom posljednjih dvaju desetljeća. Još od kasnih osamdesetih i ranih devedesetih švedska je politika tržišta rada ponajprije usmjerena na »aktiviranje« građana, pomažući im u prijelazu iz pasivne »socijalne ovisnosti« u aktivno »samozapošljavanje«. S »poticajnim« politikama tržišta rada devedesetih, rad je postupno, umjesto temeljnoga socijalnog prava, postao dužnost.

Ključne riječi: workfare, aktivacija, politika tržišta rada, zapošljivost, isključenost 